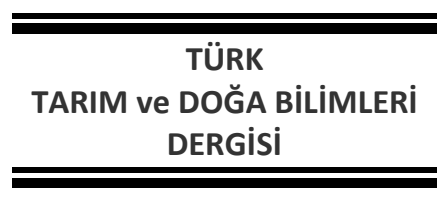

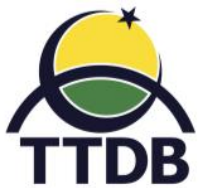

www.dergipark.gov.tr/turkjans

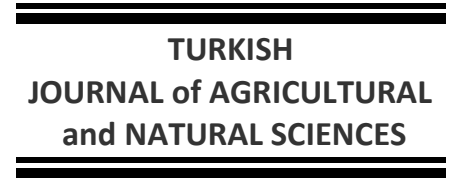

Araştırma Makalesi

\title{
Bartın Koşullarında Tritikale Çeşitlerinin Yem Verim Potansiyellerinin Değerlendirilmesi
}

\author{
Ayşe GENÇ LERMi ${ }^{1 *}$, Şahin PALTA ${ }^{2}$
}

${ }^{1}$ Bartın Üniversitesi Meslek Yüksekokulu Bitkisel ve Hayvansal Üretim Bölümü, Bartın

${ }^{2}$ Bartın Üniversitesi Orman Fakültesi Orman Mühendisliği Bölümü, Bartın

*Sorumlu yazar: agenclermi@bartin.edu.tr

Geliş Tarihi: 17.07.2018

Düzeltme Geliş Tarihi: 24.09.2018

Kabul Tarihi: 04.10.2018

\section{Özet}

Bu araştırma Bartın ilinde farklı tritikale çeşitlerinin yem verim potansiyelini belirlemek amacı ile iki yıl süre ile yürütülmüştür. Araştırma tesadüf blokları deneme deseninde üç tekerrülü olarak kurulmuştur. Denemede materyal olarak Tatlıcak 97, Melez 2001, Mikham 2002, Karma 2000 ve Presto çeşitleri kullanılmıştır. Bitkiler süt olum-hamur olum döneminde iken hasat yapılmıştır. Araştırma sonuçlarına göre incelenen özellikler bakımından en yüksek değerler Presto çeşidinden elde edilmiştir. İki yılın birleştirilmiş analizine göre en yüksek yeşil ot verimi, kuru madde verimi ve ham protein verimi sırasıyla $2926.7 \mathrm{~kg} \mathrm{da}^{-1}, 1381 \mathrm{~kg} \mathrm{da}^{-1}$ ve $148.9 \mathrm{~kg} \mathrm{da}^{-1}$ olarak Presto çeşidinden elde edilmiştir. En yüksek ham protein oranı \%11 ile Karma 2000 çeşidinden elde edilmiştir. Tritikale çeşitlerinin bölgeye adaptasyonun iyi olduğu ve yem verimlerinin tatminkâr olduğu sonucuna varılmıştır. Bölgede fazla tanınmayan tritikale bitkisinin tarımının yaygınlaştırılması gerektiği düşünülmektedir.

Anahtar kelimeler: Tritikale, yeşil ot verimi, kuru madde verimi, ham protein verimi.

\section{Evaluation of Forage Yield Potentials of Triticale Varieties under Bartın Conditions}

\begin{abstract}
This study was carried out for two years with the purpose of determining the forage yield potential of different triticale varieties in Bartın province. The study was established as a randomized complete block trial design with three replicates. The plants were harvested during the milk-dough period. According to the results of the research, the highest values were obtained from the Presto variety. According to the combined analysis of the two years, the peak herbage yield, dry matter yield and crude protein yield were obtained from the Presto variety as $2926.7 \mathrm{~kg} \mathrm{da}^{-1}, 1381 \mathrm{~kg} \mathrm{da}^{-1}$ and $148.9 \mathrm{~kg} \mathrm{da}^{-1}$, respectively. The peak crude protein ratio was obtained from Karma 2000 with $11 \%$. It has been concluded that the triticale varieties have good adaptation to the region and the forage yields are satisfying. It is thought that the cultivation of the triticale plant, which is not well known in the region, should be promoted.
\end{abstract}

Key words: Triticale, herbage yield, dry matter yield, crude protein yield.

\section{Giriş}

Tahıl hasılları otlatma, kuru ot ya da silo yemi olarak verim düzeyi farklı hayvanların beslenmesinde yalın yada karışık ekim şeklinde kullanılabilmektedir (Keleş, 2014). Buna karşılık ülkemizde tahıllar geleneksel olarak anız otlatmasında ve saman olarak hayvan beslenmesinde kullanılmaktadır (Büyükburç 1993). Adaptasyon kabiliyeti yüksek, marjinal koşullarda yetiştirilebilen bir tahıl türü olan tritikale bu özellikleri ile diğer tahıllardan ayrılmaktadır. Çavdar ve buğday melezi olan tritikale tanelerinin, un kalitesinin düşük olması nedeniyle daha çok hayvan beslemede kullanılmaktadır. Tritikale bitkisi buğdaydan \%20 daha fazla yem üretmekte olup, yem kalitesi de çavdar ve buğdaydan daha yüksektir (Koch ve Paisley, 2002). Tritikale yüksek protein verimi ve aminoasit içeriği bakımından iyi bir yem kaynağıdır (Kaplan ve ark., 2015). 
Türkiye'de yem bitkileri ekiliş alanı 18662577 ha olup yem bitkileri içerisinde en fazla 6620459 ha ile yonca ve 4105412 ha (Özkan ve Şahin Demirbağ, 2016) ile silajlık mısır yetiştiriciliği yapılmaktadır. Sulu tarım alanlarında mısır ve yonca bitkisi ile rekabete giremeyen tritikale bitkisi özellikle sulanmayan alanlarda alternatif bir yem bitkisi özelliğini taşımaktadır. Marjinal alanların etkin bir şekilde değerlendirilmesi ve kaba yem açığının kapatılması açısından ülkemizde tritikale üretiminin artırılması ve yaygınlaştırılması, bunun için de bölgeye uygun çeşitlerin belirlenmesi gerekmektedir (Şentürk ve Akgün, 2014).

Ülkemizde hayvancılığın istenilen seviyeye ulaşabilmesi için yem bitkileri üretiminin ivedilikle artırılması gerekmektedir. Yem bitkileri üretiminin artırılması ile meralar üzerindeki baskıda azalacaktır. Tahılların, yetiştiriciliği açısından üreticilerin en iyi bildiği ürünler arasında olması bu bitkilerin yem amaçlı kullanımını avantaj haline getirmektedir. Serin iklim tahılları kaba yem açığının kapatılmasında önemli bir potansiyele sahiptir. Ayrıca tahıllar, tek yıllık baklagil yem bitkileri ile karışım halinde yetiştirilerek birim alandan elde edilen yem veriminin artmasını sağlamaktadır. Diğer tahıllara göre tritikale bitkisinin sahip olduğu üstünlükler farklı ekolojik koşularda tercih edilebilirliğini artırmaktadır. Tahıllarla karışık ekim şeklinin yalın baklagil ekime göre avantajları birçok çalışma ile ortaya konulmuştur (Roberts ve ark. 1989; Rauber ve ark. 2000; Karadağ ve Büyükburç, 2004; Albayrak ve ark.,2004; Göçmen ve Özaslan Parlak 2017). Tritikale, yeşil ot olarak değerlendirildiğinde tarlayı erken terk etmesi ile ikinci ürün yetiştiriciliğine de olanak sağlamaktadır. Tritikale bitkisini hayvan beslemedeki potansiyeli üzerine farklı ekolojilerde çeşitli çalışmalar yapılmıştır. Bilgili ve ark. (2009), Bursa koşullarında tritikale hatlarında bitki boyunun $111.0-129.5 \mathrm{~cm}$ arasında kuru madde veriminin 14.8-17.7 $\mathrm{t} \mathrm{ha}^{-1}$ arasında, ham protein verimini 1.13-1.60 $\mathrm{t} \mathrm{ha}^{-1}$ arasında elde ettiğini ve Akdeniz iklimine sahip bölgelerde sonbahar ekim dönemi için alternatif bir yem bitkisi potansiyeline sahip olduğunu bildirmişlerdir. Mut ve ark. (2006) Samsun koşullarında Tatlıcak 97, Melez 2001, Mikham 2002, Presto ve Karma 2000 çeşitlerinin süt - hamur olum döneminde kuru madde verimini sırasıyla $1449 \mathrm{~kg}$ $\mathrm{da}^{-1}, 1368 \mathrm{~kg} \mathrm{da}^{-1}, 1455 \mathrm{~kg} \mathrm{da}^{-1}, 1300 \mathrm{~kg} \mathrm{da}^{-1} \mathrm{ve} 1360$ $\mathrm{kg} \mathrm{da}^{-1}$ olarak, ham protein verimlerini ise sırasıyla $93 \mathrm{~kg} \mathrm{da}^{-1}, 87 \mathrm{~kg} \mathrm{da}^{-1}, 82 \mathrm{~kg} \mathrm{da}^{-1}, 97 \mathrm{~kg} \mathrm{da}^{-1} \mathrm{ve} 78 \mathrm{~kg}$ $\mathrm{da}^{-1}$ olarak elde ettiğini bildirmişlerdir. Kaplan ve ark (2015), Tatlıcak97, Melez 2001, Mikham 2002 ve Karma 2000 çeşitlerinin yeşil ot verimini sırasıyla $4134 \mathrm{~kg} \mathrm{da}^{-1}, 4776 \mathrm{~kg} \mathrm{da}^{-1}, 3805 \mathrm{~kg} \mathrm{da}^{-1} \mathrm{ve} 3882 \mathrm{~kg}$ $\mathrm{da}^{-1}$ olarak ham protein verimlerini ise sırasıyla 121 $\mathrm{kg} \mathrm{da}^{-1}, 127 \mathrm{~kg} \mathrm{da}^{-1}, 153 \mathrm{~kg} \mathrm{da}^{-1} \mathrm{ve} 109 \mathrm{~kg} \mathrm{da}^{-1}$ olarak kaydetmişlerdir. Alp (2009) Diyabakır koşullarında tescilli tritikale çeşitlerinin yeşil ot verimini 1490.9$1205.7 \mathrm{~kg} \mathrm{da}^{-1}$ arasında ham protein oranlarını ise \%10.63-11.43 arasında elde ettiğini bildirmiştir. Subhan ve ark. (2017) Pakistan koşullarında, tritikale hatlarında bitki boyu değerlerinin 106.40$120.13 \mathrm{~cm}$ arasında, yem verimlerinin ise 1130-6160 $\mathrm{kg} \mathrm{da}{ }^{-1}$ arasında değiştiğini bildirmektedirler. Karadağ ve Büyükburç (2004), yalın tritikalenin (Tatlıcak 97) kuru madde verimini $788 \mathrm{~kg} \mathrm{da}^{-1}$, ham protein oranını \%8.09 ham protein verimini ise $65 \mathrm{~kg}$ $\mathrm{da}^{-1}$ olarak elde ettiğini bildirmişlerdir. Albayrak ve ark. (2004) yalın tritikale yeşil ot verimini $1137 \mathrm{~kg} \mathrm{da-}$ 1 , kuru madde verimini $288 \mathrm{~kg} \mathrm{da}^{-1}$, ham protein verimini $30 \mathrm{~kg} \mathrm{da}^{-1}$, ham protein oranını ise \%10.39 olarak kaydetmişlerdir. Çanakkale koşullarında, yalın Karma 2000 tritikale çeşidinin yeşil ot verimi $2045.9 \mathrm{~kg} \mathrm{da}^{-1}$ ve $1587 \mathrm{~kg} \mathrm{da}^{-1}$, ham protein oranı \%9.53 ve \%7.34 olarak elde edildiğini bildirilmiştir (Yıldırım ve Özaslan Parlak, 2016; Göçmen ve Özaslan Parlak, 2017).

$\mathrm{Bu}$ araştırmada Bartın ekolojik koşullarında tescilli beş tritikale çeşidinin kışlık ekim olarak yem verim potansiyelinin belirlenmesi amaçlanmıştır. Bölgede fazla tanınmayan tritikale bitkisinin yem verim potansiyellerinin ortaya konulması ile bu bitkiye olan farkındalık seviyesinin artırılması hedeflenmiştir.

\section{Materyal ve Yöntem}

Bu araştırma Bartın ilini Akmalar köyünde 2012-2013 ve 2013-2014 vejetasyon dönemlerinde yürütülmüştür. Deneme alanından $30 \mathrm{~cm}$ derinlikten toprak örnekleri alınarak toprak özellikleri belirlenmiştir. Analiz sonuçlarına göre toprak pH'sı 7.54 ile hafif alkali, strüktürü killi özellikte, \%7.01 $\mathrm{CaCO}_{3}$ içeriği ile orta derecede kireçli, \%3.20 organik madde içeriği ile organik maddece zengindir. Araştırmanın yürütüldüğü Bartın iline ait iklim verileri Çizelge 1'de verilmiştir. İklim verileri incelendiğinde vejetasyon döneminde bitki gelişimini etkileyecek Mart (2013 yılı) ve haziran ve temmuz aylarında (2014 yılı) uzun yılar ortalamasının üzerine yağış aldığı görülmüştür.

Araştırma tesadüf blokları deneme desenine göre üç tekerrürlü olarak yürütülmüştür. Deneme parselleri $5 \times 1.4 \mathrm{~m}=7 \mathrm{~m}^{2}$ boyutunda olup sıra arası mesafe $20 \mathrm{~cm}$ olarak belirlenmiştir. Parsellere atılacak tohum miktarı $20 \mathrm{~kg} \mathrm{da}^{-1}$ hesabıyla belirlenmiştir (Genç ve ark.,1989). Ekim işlemi 15 Kasım 2012 ve 13 Kasım 2013 tarihilerinde gerçekleştirilmiştir. Araştırmada materyal olarak Tatlıcak 97, Melez 2000, Mikham 2002, Karma 2000, Presto çeşitleri kullanılmıştır. Tatlıcak 97, Melez 2000 ve Mikham 2002 Bahri Dağdaş Uluslararası Tarımsal Araştırma Enstitüsü Müdürlügünden, Presto ve Karma 2000 çeşitleri Geçit Kuşağı Tarımsal 
Araştırma Enstitüsü Müdürlüğünden temin edilmiştir. Dekara $12 \mathrm{~kg}$ saf azot ve $5 \mathrm{~kg} \mathrm{~kg} \mathrm{da}{ }^{-1}$ fosfor $\left(\mathrm{P}_{2} \mathrm{O}_{5}\right)$ hesabıyla $10 \mathrm{~kg} \mathrm{da}{ }^{-1}$ CAN (kalsiyum amonyum nitrat), $10 \mathrm{~kg} \mathrm{da}^{-1}$ DAP (diamonyum fosfat) kullanılmıştır. Azotlu gübre ilkbaharda, fosforlu gübre ise sonbaharda taban gübresi olarak uygulanmıştır.

Hasat parselin yarısı tohum verimine bırakılacak şekilde $0.5 \mathrm{~m}$ kenar tesiri çıkarıldıktan sonra $1 \mathrm{~m}^{2 \prime}$ lik kare atılarak bitkiler biçilmiştir. Hasat zamanı tritikale bitkisinin süt- hamur olum döneminde yapılmıştır. Bitkiler hasat edildikten hemen sonra tartılarak dekara yeşil ot verimleri hesaplanmıştır. Parsellerden alınan yeşil ot örnekleri $70{ }^{\circ} \mathrm{C}^{\prime}$ de sabit ağırlığa gelene kadar kurutup tartılarak kuru madde verimleri hesaplanmıştır (Martin ve ark., 1990). Kurutulan numuneler öğütülerek ham protein oranlarının belirlenmesi için hazırlanmıştır. Ham protein oranı Kjedahl metodu ile belirlenmiştir (AOAC, 1990). Kuru madde verimi ham protein oranı ile çarpılıp 100 'e bölünerek ham protein verimi $\left(\mathrm{kg} \mathrm{da}^{-1}\right)$ olarak hesaplanmıştır (Altınok ve Karakaya, 2002).

Araştırmadan elde edilen verilerin tek yönlü varyans analizi (ANOVA) İstatistik Analiz Sistemleri (SAS) programında yapılmıştır. Ortalamalar arasında ortaya çıkan farklılık $\mathrm{P} \leq 0.05$ önem derecesine göre LSD çoklu karşılaştırma testine tabi tutulmuştur.

Çizelge 1. Araştırmanın yürütldüğü2012, 2013 ve 2014 yıllarına ve uzun yılar ortalamasına ait iklim verileri.

\begin{tabular}{lcccccccccccc}
\hline & \multicolumn{4}{c}{ Sıcaklık } & \multicolumn{4}{c}{ Nispi Nem } & \multicolumn{4}{c}{ Yağış } \\
\hline Ay / Yıl & $\mathbf{2 0 1 2}$ & $\mathbf{2 0 1 3}$ & $\mathbf{2 0 1 4}$ & UYO & $\mathbf{2 0 1 2}$ & $\mathbf{2 0 1 3}$ & $\mathbf{2 0 1 4}$ & UYO & $\mathbf{2 0 1 2}$ & $\mathbf{2 0 1 3}$ & $\mathbf{2 0 1 4}$ & UYO \\
\hline Ocak & 2.7 & 5.1 & 6.2 & 4.1 & 87.0 & 85.0 & 83.1 & 81.8 & 182.1 & 176.6 & 32.1 & 113.5 \\
Şubat & 1.5 & 7.5 & 6.4 & 4.7 & 85.0 & 81.7 & 80.4 & 79.6 & 146.2 & 50.9 & 52.0 & 85.4 \\
Mart & 4.8 & 9.4 & 8.5 & 7.0 & 78.8 & 73.7 & 77.9 & 77.4 & 138.0 & $\mathbf{1 2 4 . 1}$ & 67.6 & 75.2 \\
Nisan & 13.7 & 12.3 & 12.4 & 11.2 & 69.3 & 74.8 & 76.8 & 76.2 & 31.2 & 39.2 & 44.2 & 57.4 \\
Mayıs & 16.5 & 17.7 & 16.5 & 15.6 & 80.4 & 75.8 & 77.7 & 76.4 & 37.4 & 5.8 & 91.1 & 50.0 \\
Haziran & 21.9 & 20.9 & 20.1 & 19.8 & 68.4 & 73.4 & 78.6 & 73.8 & 22.4 & 66.6 & $\mathbf{1 4 1 . 2}$ & 70.4 \\
Temmuz & 24.2 & 22.6 & 23.2 & 22.1 & 73.3 & 69.8 & 75.8 & 74.7 & 71.7 & 39.6 & $\mathbf{1 4 6 . 3}$ & 62.6 \\
Ağustos & 22.1 & 22.9 & 23 & 21.6 & 75.7 & 72.1 & 82.1 & 77.1 & 172.5 & 14.4 & 50.9 & 82.6 \\
Eylül & 18.6 & 17.2 & 18.4 & 17.7 & 79.7 & 80.5 & 85.0 & 79.7 & 20.9 & 137.6 & 123.6 & 85.7 \\
Ekim & 16.1 & 11.4 & 14.5 & 13.7 & 81.8 & 84.4 & 87.5 & 82 & 47.7 & 265.3 & 80.9 & 104.9 \\
Kasım & 11.0 & 9.7 & 10.3 & 9.1 & 84.7 & 82.2 & 83.1 & 81.8 & 46.8 & 56.1 & 92.4 & 115.0 \\
Aralık & 7.0 & 2.3 & 5.2 & 6.0 & 84.0 & 82.6 & 80.3 & 82.4 & 175.6 & 130.2 & 145.1 & 131.0 \\
\hline Ort. & 13.34 & 13.25 & 13.73 & 12.72 & 79.01 & 78.00 & 80.69 & 78.58 & 91.04 & 92.20 & 88.95 & 86.14 \\
\hline
\end{tabular}

Kaynak: Bartın Meteoroloji Müdürlüğü. UYO: Uzun Yıllar Ortalaması (52 Yıllık).

\section{Bulgular ve Tartışma}

Tescilli tritikale çeşitleri arasında bitki boyu bakımından istatistiki olarak bir fark ortaya çıkmazken yıllar arasındaki farklılık \%1 düzeyinde önemli bulunmuştur (Çizelge 2). Ham protein oranı, yeşil ot verimi, kuru madde verimi ve ham protein verimi değerleri bakımından tritikale çeşitleri arasındaki fark \%1 düzeyinde önemli bulunmuştur. Birinci yıl vejetasyon döneminde uzun yıllar ortalamasının üzerine yağış almasına bağlı olarak aynı yıl elde edilen değerler ikinci yıla göre daha yüksek elde edilmiştir. Buna bağlı olarak yıllar arasındaki fark istatistiki olarak (\%1 düzeyinde) önemli bulunmuştur. 2013 ve 2014 yıllarının birleştirilmiş ortalamalarında da benzer şekilde incelenen özellikler bakımından çeşitler arasındaki fark istatistiki olarak önemli bulunmuştur (Çizelge 2).

Çizelge 2. Tritikale çeşitlerinde bitki boyu ve ham protein oranlarına ait ortalamalar.

\begin{tabular}{|c|c|c|c|c|c|c|}
\hline & \multicolumn{3}{|c|}{ Bitki boyu (cm) } & \multicolumn{3}{|c|}{ Ham protein oranı (\%) } \\
\hline Çeşit & 2013 & 2014 & BY & 2013 & 2014 & BY \\
\hline Tatlıcak 97 & 126.2 & 120.9 & 123.6 & $8.0 \mathrm{~b}$ & $8.0 \mathrm{c}$ & $8.0 c$ \\
\hline Melez 2000 & 123.03 & 113.5 & 118.3 & $8.5 b$ & $8.2 c$ & $8.4 c$ \\
\hline Mikham 2002 & 135.1 & 116.4 & 125.8 & $10.3 a$ & $10.0 \mathrm{~b}$ & $10.2 b$ \\
\hline Karma 2000 & 124.6 & 119.3 & 122 & $11.1 a^{* *}$ & $11.0 \mathrm{a} * *$ & $11.0 a^{* *}$ \\
\hline Presto & 126.8 & 121.43 & 124.1 & $10.8 \mathrm{a}$ & $10.8 \mathrm{ab}$ & $10.8 \mathrm{ab}$ \\
\hline Ortalama & $127.16 A^{* *}$ & 118.3B & 122.7 & 9.7 & 9.6 & 9.7 \\
\hline LSD & 10.85 & 8.85 & 6.83 & 1.14 & 0.84 & 0.65 \\
\hline
\end{tabular}

BY: Birleştirilmiş Yıllar 
Tritikale çeşitlerinin Bartın koşullarında 2013 yılı ortalaması $127.16 \mathrm{~cm}$ iken 2014 yılında 118.3 cm'e düşmüştür. Yıllar arasındaki farklılık birinci yılda düşen yağış oranın daha fazla olmasından kaynaklanmıştır. Araştırmanın yürütüldüğü ilk yıl en yüksek değer $135.1 \mathrm{~cm}$ ile Mikham 2002 çeşidinden elde edilmiştir (Çizelge 2). İkinci yıl da ise en yüksek bitki boyu Presto çeşidinden elde edilmiştir. İki yılın ortalamasına göre çeşitlerin bitki boyu ortalamaları $127.7 \mathrm{~cm}$ olarak elde edilmiştir. Bilgili ve ark. (2009), Bursa koşullarında tritikale hatlarında bitki boyunun 111.0-129.5 cm arasında, Tayyar ve Kahrıman (2016) Biga şartlarında tescilli tritikale çeşitlerinin bitki boyunu 117.3-126.9 cm arasında elde ettiklerini bildirmişlerdir. Araştırıcıların elde ettiği değerler, elde ettiğimiz değerle uyum göstermektedir. Buna karşılık bazı araştırıcıların (Mut ve ark., 2006; Akgün ve ark., 2007; Alp, 2009; Kutlu ve Kınacı, 2011; Mut ve Erbaş Köse, 2018) elde ettiği değerlerden daha yüksek bitki boyu değerleri elde edilmiştir.

Ham protein oranı bakımından her iki yılda ve birleştirilmiş yılların ortalamasında çeşitler arasında farklılık ortaya çıkmıştır. 2013 yılı en yüksek ham protein oranı sırasıyla \%11.1, \%10.8 ve 10.03 ile Karma 2000, Presto ve Mikham 2002 çeşitlerinden elde edilmiştir (Çizelge 2). 2014 yılında ve birleştirilmiş yıların ortalamalarında en yüksek ham protein oranı \%11.0 ile Karma 2000 çeşidinden elde edilmiştir. İki yılın ortalamasına göre ortalama ham protein oranı \%9.7 olarak kaydedilmiştir. Alp (2009), Diyarbakır koşullarında tescilli tritikale çeşitlerinin ham protein oranlarını \%10.63-11.43 arasında elde ettiğini bildirmiştir. Araştırıcının elde ettiği sonuçlar ile araştırmamızdan elde edilen sonuçlar paralellik göstermektedir. Karadağ ve Büyükburç (2004, (Tatlıcak 97) ham protein oranını \%8.09, Yıldırım ve Özaslan Parlak (2016) ve Göçmen ve Özaslan Parlak (2017) ise Karma 2000 çeşidinde sırasıyla \%9.53 ve \%7.34 olarak kaydetmişlerdir.

Tritkale çeşitlerinin yeşil ot verimi araştırmanın yürütüldüğü yıllarda ve iki yılın ortalamalarında en yüksek Presto çeşidinden elde edilmiştir. Birinci yıl yeşil ot verimi 2026-3080 kg da${ }^{1}$ arasında elde edilmiş olup en düşük değer Melez 2001 çeşidinden elde edilmiştir (Çizelge 3). İkinci yıl en yüksek yeşil ot verimi $2773.3 \mathrm{~kg} \mathrm{da}^{-1}$ ile Presto çeşidinden elde edilirken diğer çeşitler arasında farklılık ortaya çıkmamıştır. İklim faktörlerine bağlı olarak ikinci yıl yeşil ot verimleri düşmüştür. Bu durum yıllar arasında farklılığın çıkmasına sebep olmuştur. Birinci yıl yeşil ot verimi ortalaması 2467.3 kg da-1 iken ikinci yıl $2094.0 \mathrm{~kg} \mathrm{da}^{-1}$ olarak elde edilmiştir. İki yılın birleştirilmiş ortalamalarına göre en yüksek yeşil ot verimi yine $2926.7 \mathrm{~kg} \mathrm{da}^{-1}$ ile Presto çeşidinden elde edilmiş olup bunu $2291.7 \mathrm{~kg}$ da $^{-1}$ ile Karma 200 çeşidi takip etmiştir. Alp (2009) yaptığı çalışmada yeşil ot verimini $1490.9-1205.7 \mathrm{~kg}$ $\mathrm{da}^{-1}$ arasında elde ettiğini bildirmiştir. Yıldırım ve Özaslan Parlak (2016) yeşil ot verimini 2045.9 kg da1, Göçmen ve Özaslan Parlak (2017) $1587 \mathrm{~kg} \mathrm{da}^{-1}$, Albayrak ve ark. (2004) 1137 kg da-1 olarak elde ettiklerini bildirmişlerdir. Yeşil ot verimi diğer araştırıcıların elde ettiği sonuçlar ile benzerlik göstermektedir. Buna karşılık Kaplan ve ark (2015), Tatlıcak97, Melez 2001, Mikham 2002 ve Karma 2000 çeşitlerinin yeşil ot verimini sırasıyla $4134 \mathrm{~kg}$ $\mathrm{da}^{-1}, 4776 \mathrm{~kg} \mathrm{da}^{-1}, 3805 \mathrm{~kg} \mathrm{da}^{-1}$ ve $3882 \mathrm{~kg} \mathrm{da}^{-1}$ olarak kaydetmişlerdir. Araştırıcının elde ettiği değerler araştırmamızdan elde edilen yeşil ot verimi değerlerine göre daha yüksek olmuştur.

Kuru madde veriminde yeşil ot verimine paralel sonuçlar elde edilmiştir. Her iki yılda da en yüksek kuru madde verimi Presto çeşidinden elde edilmiştir. En düşük verim 2013 yılında Melez 2001 (790.6 kg da-1) çeşidinden, 2014 yılında Mikham $2002\left(712.0 \mathrm{~kg} \mathrm{da}^{-1}\right)$ çeşidinden elde edilmiştir. Ortalamalara göre de benzer sonuçlar elde edilmiştir. En yüksek kuru madde verimi 2013 yılında $1434.1 \mathrm{~kg} \mathrm{da}^{-1}$, ikinci yılda $1328 \mathrm{~kg} \mathrm{da}^{-1}$ olarak belirlenmiştir (Çizelge 3). Ortalama kuru madde verimi $1021.2 \mathrm{~kg} \mathrm{da}^{-1}$ 'dır. Elde ettiğimiz sonuçlar Bilgili ve ark. (2009), Karadağ ve Büyükburç (2004), Lithourgidis ve ark. (2006), Yücel ve Avcı (2009)'nın elde ettiği sonuçlar ile uyum göstermektedir. Mut ve ark. (2006) Tatlıcak 97, Melez 2001, Mikham 2002, Presto ve Karma 2000 çeşitlerinin kuru madde verimini sırasıyla $1449 \mathrm{~kg} \mathrm{da}^{-1}, 1368 \mathrm{~kg} \mathrm{da}^{-1}, 1455 \mathrm{~kg}$ $\mathrm{da}^{-1}, 1300 \mathrm{~kg} \mathrm{da}^{-1}$ ve $1360 \mathrm{~kg} \mathrm{da}^{-1}$ olarak elde ettiklerini bildirmişlerdir. Araştırıcıların elde ettikleri değer Presto çeşidinden elde ettiğimiz değer ile uyum gösterirken diğer çeşitlerde elde edilen değerlerden yüksek olmuştur. Bu durumun çeşitler arasındaki ekolojik koşullara karşı adaptasyon kabiliyetlerindeki farklılıktan kaynaklanmış olabileceği kanaatine varılmıştır.

Ham protein verimi bakımından incelenen diğer özelliklerde olduğu gibi 2013 yılı ve 2014 yılı ve iki yılın ortalamalarında sırasıyla en yüksek değerler $155.2 \mathrm{~kg} \mathrm{da}^{-1}, 142.5 \mathrm{~kg} \mathrm{da}^{-1}$ ve $148.9 \mathrm{~kg} \mathrm{da}^{-1}$ ile Presto çeşidinden elde edilmiştir (Çizelge 3). Araştırmanın yürütüldüğü iki yılda da Tatlıcak 97, Melez 2001 ve Mikham 2002 çeşitleri arasında istatistiksel olarak farklılık ortaya çıkmamıştır. Ortalama ham protein verimi $100.6 \mathrm{~kg} \mathrm{da}^{-1}$ olarak belirlenmiştir. Bilgili ve ark. (2009), tritikale ham protein verimini 113-160 $\mathrm{kg} \mathrm{da}^{-1}$ olarak kaydetmişlerdir. Elde ettiğimiz sonuçlar Karadağ ve Büyükburç (2004), Mut ve ark. (2006), Albayrak ve ark. (2004), Önal Aşçı ve Eğritaş, (2017)'ın elde ettikleri sonuçlardan yüksek, Kaplan ve ark (2015)'nın elde ettikleri değerlerden düşük olduğu belirlenmiştir. Kuru madde verimleri ve ham protein oranlarındaki değişikliklere bağlı olarak ham protein verimlerinde farklılıklar ortaya çıkmıştır. 
Çizelge 3. Tritikale çeşitlerinin yeşil ot, kuru madde ve ham protein verimine ait ortalamalar.

Çeşit Yeşil ot verimi $\left(\mathrm{kg} \mathrm{da}^{-1}\right) \quad$ Kuru madde verimi $\left(\mathrm{kg} \mathrm{da}^{-1}\right) \quad$ Ham protein verimi $\left(\mathrm{kg} \mathrm{da}^{-1}\right)$

\begin{tabular}{|c|c|c|c|}
\hline \multicolumn{4}{|c|}{2013} \\
\hline Tatlıcak 97 & $2430 \mathrm{cb}$ & $1066.9 b c$ & $85.1 b$ \\
\hline Melez 2001 & $2026.7 c$ & $790.6 d$ & $67.4 b$ \\
\hline Mikham 2002 & $2266.7 \mathrm{cb}$ & $956.9 \mathrm{dc}$ & $99.0 b$ \\
\hline Karma 2000 & $2533.3 b$ & 1232.3ab & $137.4 a$ \\
\hline Presto & $3080 a^{* *}$ & $1434.1 a^{* *}$ & $155.2 \mathrm{a} * *$ \\
\hline Ortalama & $2467.3 A^{* *}$ & 1096.2A** & $108.8 A^{* *}$ \\
\hline LSD & 417.99 & 237.1 & 32.15 \\
\hline \multicolumn{4}{|c|}{2014} \\
\hline Tatlıcak 97 & $2026.7 b$ & $941.3 \mathrm{cb}$ & $76.2 c$ \\
\hline Melez 2001 & $1823.3 b$ & $758.3 \mathrm{~cd}$ & $62.5 c$ \\
\hline Mikham 2002 & $1796.7 b$ & $712 d$ & $71.5 c$ \\
\hline Karma 2000 & $2050 b$ & $991.4 b$ & $108.9 b$ \\
\hline Presto & $2773.3 a^{* *}$ & $1328 \mathrm{a} * *$ & $142.5 a * *$ \\
\hline Ortalama & 2094B & $946.2 B$ & $92.3 \mathrm{~B}$ \\
\hline LSD & 289.51 & 220 & 19.96 \\
\hline \multicolumn{4}{|c|}{ Birleştirilmiş Yıllar } \\
\hline Tatlıcak 97 & $2282.3 b c$ & $1004 b$ & $80.7 \mathrm{~cd}$ \\
\hline Melez 2001 & $1925 d$ & $774.5 c$ & $64.9 \mathrm{~d}$ \\
\hline Mikham 2002 & 2031.7cd & $843.4 c$ & $85.3 c$ \\
\hline Karma 2000 & $2291.7 b$ & 1111.9b & $123.2 b$ \\
\hline Presto & $2926.7 a * *$ & $1381 a * *$ & $148.9 a * *$ \\
\hline Ortalama & 2280.7 & 1021.2 & 100.6 \\
\hline LSD & 230.4 & 141.57 & 16.88 \\
\hline
\end{tabular}

$$
* * \mathrm{P}<0.01
$$

\section{Sonuç ve Öneriler}

Araştırmadan elde edilen verilere göre denemeye alınan çeşitler arasında Presto çeşidi ön plan çıkmıştır. İncelenen tüm özelliklerde bitki boyu hariç en yüksek değerler Presto çeşidinden elde edilmiştir. Presto çeşidini Karma 2000 ve Tatlıcak 97 çeşidi takip etmiştir. Sonuç olarak, tritikale bitkisinin Bartın ve benzer ekolojik koşullarda yem bitkisi olarak değerlendirilme potansiyelinin yüksek olduğu belirlenmiştir. Tritikale, tarımı birçok yetiştirici tarafından iyi bilinen tahıllar grubunda yer alması bu bitkini yem amaçlı değerlendirilmesi açısından bir avantaj teşkil etmektedir. Ancak bölgede yem amaçlı olarak daha çok yulaf yetiştiriciliğinin yapılması nedeniyle tritikale, yulaf ve diğer serin iklim tahılları ile karşılaştırmalı araştırmalara ve diğer tritikale çeşitlerinin yem verim potansiyellerinin belirlenmesi ile ilgili çalışmalara ihtiyaç duyulmaktadır.

\section{Kaynaklar}

Akgün, İ., Kaya, M., Altındal, D. 2007. Isparta ekolojik koşullarında bazı tritikale hat/çeşitlerinin verim ve verim unsurlarının belirlenmesi. Mediterranean Agricultural Sciences, 20(2): 171-182.

Albayrak, S., Güler, M., Töngel, M.Ö. 2004. Effects of seed rates on forage production and hay quality of vetch-triticale mixtures. Asian Journal of Plant Sciences, 3(6): 752-756.

Alp, A. 2009. Diyarbakır kuru koşullarında bazı tescilli tritikale (Xtriticosecale Wittmack) çeşitlerinin tarımsal özelliklerinin belirlenmesi. YYÜ Tarım Bilimleri Dergisi, 19(2): 61-70.

Altınok, S., Karakaya, A. 2002. Forage yield of different alfalfa cultivars under Ankara conditions. Turkish Journal of Agriculture and Forestry, 26(1): 11-12.

AOAC 1990. Official Method of Analysis. 15th. edn. Association of Official Analytical Chemist, Washington, DC.USA.

Bilgili, U., Cifci, A.E., Hanoglu, H., Yagdi, K., Acikgoz, E. 2009. Yield and quality of triticale forage. Journal of Food Agriculture and Environment, 7(3\&4): 556-560.

Büyükburç, U. 1993. Effect of fertilizers and resting on the overgrazed semi- arid ranges of Central Anatolia. XVII. International 
Grassland Congress, New Zealand-Australia, 62-64.

Genç, İ., Ülger, A.C., Yağbasanlar, T. 1989. Türkiye için yeni bir tahıl cinsi tritikale. Hasad Dergisi,5(53): 14-15.

Göçmen, N., Özaslan Parlak, A. 2017. Yem bezelyesi ile arpa, yulaf ve tritikale karışım oranlarının belirlenmesi. Çanakkale Onsekiz Mart Üniversitesi Ziraat Fakültesi Dergisi, 5(1): 119-124.

Kaplan, M., Yılmaz, M.F., Kara, R. 2015. Variation in hay yield and quality of new triticale lines. Ankara University, Journal of Agricultural Sciences, 21(2015): 50-60.

Karadag, Y., Buyukburc, U. 2004. Forage qualities, forage yields and seed yields of some legume-triticale mixtures under rainfed conditions. Acta Agriculturae Scandinavica. Section B-Soil and Plant Science, 54(3): 140148.

Keleş, G. 2014. Farklı gelişme dönemlerinde hasat edilmiş tritikale hasılında morfolojik unsurların besin değeri. Hayvansal Üretim, 55(1): 1-6.

Koch, W.D., Paisley, S. 2002. Forages of All Seasons - cereal crops: management for supplemental and emergency forage. Can. J. Plant Sci, 32: 121-128.

Kutlu, İ., Kınacı, G. 2011. Sulu ve Kuru koşullara uygun tritikale genotiplerinde tarımsal özelliklerin belirlenmesi. Anadolu Üniversitesi Bilim ve Teknoloji Dergisi-C Yaşam Bilimleri ve Biyoteknoloji 1(1): 71-82.

Lithourgidis, A.S., Vasilakoglou, I.B., Dhima, K.V., Dordas, C.A., Yiakoulaki, M.D. 2006. Forage yield and quality of common vetch mixtures with oat and triticale in two seeding ratios. Field Crops Research, 99(2): 106-113.

Martin, R.C., Harvey, H.D., Smith, D.L. 1990. Intercropping corn and soybean for silage in a cool temperate region; yield, protein and economic effects. Field Crops Research, 23: 295-310.

Mut, Z., Albayrak, S., Töngel, Ö. 2006. Tritikale (Xtriticosecale Wittmack) Hatlarının tane verimi ve bazı özelliklerinin belirlenmesi. Ankara Üniversitesi Ziraat Fakültesi Tarım Bilimleri Dergisi, 12(1): 56-54.

Mut, Z., Erbaş Köse, Ö.D. 2018. Tritikale genotiplerinin tane verimi ve bazı kalite özellikleri. Anadolu Tarim Bilimleri Dergisi, 33(1): 47-55.

Önal Aşçı, Ö., Eğritaş, Ö. 2017. Determination of forage yield, some quality properties and competition in common vetch-cereal mixtures. Journal of Agricultural Sciences, 23(2): 242-252.
Özkan, U, Şahin Demirbağ, N 2016. Türkiyede kaliteli kaba yem kaynaklarının mevcut durumu. Türkiye Bilimsel Derlemeler Dergisi, 9(1):23-27.

Rauber, R., Schmidtke, K., Kimpel-Freund, H. 2000. Konkurrenz und ertragsvorteile in gemengen aus erbsen (Pisum sativum L.) und hafer (Avena sativa L.). Journal of Agronomy and Crop Science, 185(1): 33-47.

Roberts, C.A., Moore, K.I., Johnson, K.D. 1989. Forage quality and yield of wheat-vetch at different stages of maturity and vetch seeding rates. Agronomy Journal, 81(1): 5760.

Subhan, F., Khakwani, A.A., Khan, A.A., Farullah, G., Ali Khan, A., Saddozai, U.K. 2017. Forage and grain production dynamics of triticale sown on different dates under irrigated conditions. Agriculture and Forestry, 63(4): 107-112.

Şentürk, Ş., Akgün, i. 2014. Bazı tritikale genotiplerinin batı geçit bölgesinde verim ve verim unsurlarının belirlenmesi. SDÜ Ziraat Fakültesi Dergisi, 9(1): 16-26.

Tayyar, Ş., Kahrıman, F. 2016. Biga şartlarında yetiştirilen tritikale genotiplerinin verim ve bazı kalite özelliklerinin belirlenmesi. Adnan Menderes Üniversitesi Ziraat Fakültesi Dergisi, 13(2): 23-31.

Yıldırım, S., Özaslan Parlak, A. 2016. Tritikale ile bezelye, bakla ve fiğ karışım oranlarının belirlenerek yem verimi ve kalitesine etkileri. ÇOMÜ Ziraat Fakültesi Dergisi, 4(1): 77-83.

Yucel, C., Avci, M. 2009. Effect of different ratios of common vetch (Vicia sativa L.)-triticale (Triticosecale Whitt) mixtures on forage yields and quality in Cukurova plain in Turkey. Bulgarian Journal of Agricultural Science, 15(4): 323-332. 